\title{
Do private school girls marry rich?
}

\author{
Francis Green \\ Francis.green@ucl.ac.uk \\ Golo Henseke \\ Samantha Parsons \\ Alice Sullivan \\ Richard Wiggins
}

(Received January 2018

\author{
UCL Institute of Education, UK \\ UCL Institute of Education, UK \\ UCL Institute of Education, UK \\ UCL Institute of Education, UK \\ UCL Institute of Education, UK
}

Revised March 2018) http://dx.doi.org/10.14301/llcs.v9i3.496

\section{Abstract}

This paper considers for the first time whether there is school-type homogamy, and whether for women there are significant advantages from private schooling as a consequence of school-type homogamy. Its focus is Britain, where a private education is associated with substantial labour market advantages and where access is socially exclusive. We find that privately educated women are 7 percentage points more likely than observably similar state-educated women to marry privately educated men. Privately educated married women have husbands who earn 15\% higher pay, according to the BHPS-UKHLS panel ( $20 \%$ at age 42 , according to the British Cohort Study). Causation is not established and considerable caution would be needed if interpreting these associations as reflecting causal effects from private schools. The findings nevertheless raise anew the issue of the negative association between Britain's private schooling and social mobility.

\section{Keywords}

Private school; pay; social mobility; homogamy; marriage

\section{Introduction}

Historically, education in Britain for affluent families' girls in private schools focused on domestic economy and "accomplishments", rather than intellectual pursuits, in a socially segregated setting, ready for a suitable marriage within their class (Gathorne-Hardy, 1977). In the last part of the $19^{\text {th }}$ century a number of pioneering schools emerged with a more academic curriculum, forerunners of a convergence between the orientations of boys and girls schools in the last half-century, as women raised their labour force participation. Nevertheless, the idea that a private education might be a springboard (intended or not) for securing marriage to a high-earnings husband retains its place in some public discourse even in modern times. ${ }^{1}$ This expectation draws some credence from the extensive evidence of homogamy by education and by social class in modern societies (see the review by Schwartz, 2013). Homogamy within social class is, of course, nothing new. The last half-century, however, has seen a transformation in the importance of education for economic and social success (Goldin \& Katz, 2008). Since in Britain the dividing line between state and private education is especially sharp, it can be suggested that homogamy associated with education level would additionally take the form of homogamy associated with school- 
type (interpreted here as private or state). Yet hitherto no studies have investigated whether privately educated people are disproportionately likely to marry others who are privately educated, or whether there is any return to private schooling via marriage.

This paper examines whether there is homogamy within school-type in England, and whether for women there are significant returns to private schooling through marriage. Private education is associated with substantial labour market advantages in Britain, including greater access to high-status and influential jobs and a large pay premium (Dearden, Ferri, \& Meghir, 2002; Green, Machin, Murphy, \& Zhu, 2012; McKnight, 2015; Green, Henseke, \& Vignoles, 2017; Green, Parsons, Sullivan, \& Wiggins, 2018). Unsurprisingly, the schools' pupil populations are drawn from highincome families, in many of which one or both parents have themselves been privately educated (Dearden, Ryan \& Sibieta, 2011; Green, Anders, Henderson, \& Henseke 2017). The high labour market returns and the exclusivity together lead, it is held, to a constraint on social mobility and a buttress for high levels of inequality in Britain. Any additional return to private schooling via marriage to a higher-earning spouse would enhance such effects, while at the same time altering the calculus of parents' school choice.

The institutional separation between the private and state sectors is marked by a distinct and looser form of regulation in the private sector. British private schools can admit whomever they choose, charge whatever fees they like, determine their own budgets within market constraints, and manage and govern independently. They are subject only to their own voluntary regulatory body and, more pertinently, the pressures of the public national examination system. While many are engaged in minor relationships (such as the sharing of facilities) with neighbourhood state schools, their relationships are mainly with other private schools. The private schools have their own sectoral institutions (at the pinnacle of which is the Independent Schools Council). Unlike in the majority of other country's private sectors, Britain's private schools now receive virtually no direct public subsidies. There used to be some subsidy through the Assisted Places Scheme that ran from 1981 till 1997 (Power, Whitty, \& Wisby, 2006), and historically local government would subsidise boarding school places in private schools for children in special circumstances. But such injections of funding have been virtually absent in the $21^{\text {st }}$ century. ${ }^{2}$ The private schools do benefit, however, from some tax concessions, which, for example, lower their local business taxes by $80 \%$; however, these subsidies are relatively minor, amounting to only a few percent of their turnover. There are $82 \%$ of private schools with the status of charities, which among other advantages allows them to accept donations favourably; $16 \%$ are forprofit institutions.

This absence of substantive government funding is one reason why the private cost is especially high - in 2017 the average annual fee before any extras was $£ 13,818$ for day school and $£ 32,259$ for boarding school. Since the 1980s the schools have continuously elevated the fees in a competition over facilities and small class sizes. The 2017 fees were approximately three times the 1980 fees in real terms, and the teacher-pupil ratio has become twice as high in the private sector as in the state sector. To compete with state education, private schools in Britain have increased their emphasis on academic and cultural achievements (Turner, 2015; Peel, 2015;), not least so their pupils could gain access to high-ranked universities (Boliver, 2013). The private school sector in Britain arrived, at the start of this century, in good financial and academic health, still largely serving the increasingly affluent professional and managerial classes. The proportion of school children in private school has remained relatively steady, at between 6 and $7 \%$ for both sexes since the 1980s, despite the fee rises. Moreover, participation increases with age, up to approximately $17 \%$ at upper secondary level, which occurs in part because many state school pupils have left school at 16 (even though they may stay in education). There is a disproportionate concentration of private schools in the South East and in London. About one in four schools take boarders, and one in five are single sex, unlike in the state sector where single-sex education is rare ( $2 \%$ of schools) and boarding even rarer (less than $1 \%)$. With few exceptions, the elite sector of schooling is in the private sector, and the privately educated, in addition to enjoying the earnings premiums noted above, which they receive as a result of their high education levels and posteducation labour market advantages, continue to dominate public life in Britain with vastly 
disproportionate representation in influential positions (Kirby, 2016).

In this context, it is important to understand better the links between private schooling and marriage outcomes in the modern era. The argument we develop below may be concisely stated as follows. Private schooling for women may lead to an economic return via the marriage market in two ways. First, owing to the high quality of private schooling in Britain, combined with educational homogamy, privately schooled women are more likely to marry a well-educated husband who in turn will therefore have a better job and higher earnings. Second, we hypothesise that there is also a tendency for 'school-type homogamy', in which privately-educated women are more likely (than with a random draw) to marry privately educated men; since privately educated men earn a premium beyond their education premium in Britain's labour market, this also yields a gain for the women who marry them.

While much of the argument would apply also to men, our focus here is on the marriage returns from private schooling for women, as manifested in their husband's labour market outcomes. We do this in part to reflect the historical role of girls' education, noted above, as a path to a good marriage rather than academic achievement. In addition, the ownwage returns to education, to private schooling and to marriage are all known to be gender specific (e.g. Silles, 2007; Green et al., 2012; Antonovics \& Town, 2004).

To examine these marriage market returns from private schooling for females, we required suitable longitudinal data covering both partners. Accordingly, we use the British Household Panel Study combined with its successor the UK Household Longitudinal Study (BHPS-UKHLS); we also use data drawn from the 2012 wave of the longitudinal British Cohort Study when all cohort members were aged 42. After setting out our theoretical expectations in detail in the next section, we follow with a description of the data. The subsequent section presents findings concerning school-type homogamy. We investigate whether there is, as expected, an above-random chance that the husbands of privately educated women had also been privately educated, even after controlling for the women's social background. In Results, we investigate the association between women's private schooling and their husband's earnings, followed by our conclusions.

\section{School-type homogamy and the marriage market return to private education}

In this section, we outline how school-type homogamy might arise in Britain, partly as a byproduct of the well-known phenomenon of homogamy by education level. This argument then paves the way for an analysis of the benefits of a private education for women, in terms of the earnings of future marriage partners.

The tendency for people to marry or partner with others of similar educational status is well established (Elder Jr, 1969; Uunk, Ganzeboom \& Róbert, 1996; Blackwell, 1998; Kalmijn, 1998; Reynolds, Baker \& Pedersen, 2000; Blossfeld \& Timm, 2003; Schwartz \& Mare, 2005; Schwartz, 2013; Greenwood, Guner, Kocharkov \& Santos, 2014) and has been implicated in growing resource inequalities between households (Blossfeld \& Buchholz, 2009). Homogamy is argued to result from matched preferences, and from competition in the marriage market for spouses with valuable traits. Blossfeld (2009) adds that the education system acts as a marriage market, with expanding post-school education providing contact opportunities for equally educated men and women at a transitional time when partner search is often high. Educational homogamy contributes significantly to both economic inequality and low inter-generational social mobility in Britain (Ermisch, Francesconi \& Siedler, 2006). The trends in educational homogamy across countries are mixed (Blossfeld, 2009). There is evidence that educational homogamy declined in Britain between 1973 and 1986/7, but rebounded upwards between 1986/7 and 1994/5 (Halpin \& Chan, 2003). In the United States, by contrast, there is a lack of consensus as to whether educational homogamy has risen or remained stable (Siow, 2015; Gihleb \& Lang, 2016, though any change seems not, in itself, to have had a large effect on inequality (Schwartz, 2013; Breen \& Andersen, 2012; Greenwood et al., 2014). Increases have been attributed to the changing socio-demographic composition of the population, changes in marriage rates, and more generally to a societal modernisation trend whereby achieved characteristics have become more important, relative to social and ethnic 
background, for partner selection; rising inequality is another factor.

Educational homogamy has implications for matching in terms of school type, because private schooling in Britain yields a substantial return in terms of educational achievement. Studies have shown that private schooling delivers (on average) superior performance in nationally validated exams, and in access to universities, especially high-ranking universities which select on academic achievement (Dearden et al., 2002; Bukodi \& Goldthorpe, 2011; Gregg \& Macmillan, 2010; Goodman, Gregg \& Washbrook, 2011; Crawford, Goodman \& Joyce, 2010; Jerrim, Parker, Chmielewski \& Anders, 2015; Sullivan, Parsons, Wiggins, Heath \& Green, 2014). ${ }^{3}$ A consequence of this private schools' quality advantage is that educational homogamy is expected to be partially reflected in 'school-type homogamy': an above-random tendency for privately educated women to marry privately education men.

We also conjecture that school-type homogamy may arise directly, as a consequence of the shared values and social networks inculcated through private education, and from the spatial and social clustering of the privately educated. These factors can apply at multiple stages - at school and thereafter in universities, workplaces or other social networks.

British private secondary schools were traditionally single-sex, and the development of long-lasting romantic relationships was accordingly limited during school years. Nevertheless, even though many girls' schools came to fully embrace academic learning objectives, these schools were often largely concerned with preparing girls for an advantageous marriage (Gathorne-Hardy, 1977; Blandford, 1977). By the 1980s, the majority of the (traditionally elite, male) HMC (Headmasters' Conference) private schools admitted girls as well as boys (Walford, 1983). This change was motivated largely by economic pressures on the private schools, but Walford also cites views that girls would act as a civilising influence, and help the boys to learn how to interact with the opposite sex. There is only small-scale qualitative evidence for relationship development within or among private schools and its link to the reproduction of privileged status (Maxwell \& Aggleton, 2014a, 2014b). For those who do not pursue their education further, post-school networks through family and work are likely to be disproportionately within school type, owing to shared values and friendship networks developed within and surrounding the schools (Ashley, Duberley, Sommerlad \& Scholarios, 2015; Cookson \& Persell, 1985).

For those who proceed to university, however, it could be expected that social networks broaden beyond the cultural range of potential partners encountered by the privately educated in their school days. Most of the higher-educated adult population in Britain have been to university at a time when no or low fees were payable, and many would have been in receipt of maintenance grants. Thus universities have been substantially more socially inclusive than private schools, and we would expect that school-type homogamy would be less frequent among those who proceed to university after school than among those who do not go to university. Nevertheless, a much higher proportion of private school leavers than of state school leavers go to university, and these privately educated students are concentrated in high-ranking universities (Boliver, 2013). The concentration is yet greater in certain subjects (arts and humanities), which is notable given recent Europe-wide evidence of field-of-study assortative mating (Bičáková \& Jurajda, 2016). This spatial and disciplinary concentration of privately-educated people at a time of life when a notable part of mate selection takes place could therefore limit the extent to which going to college diminishes the probability of intra school-type mating.

While university is an important site of mate selection, selection and marriage also occur later in the context of work or other domains. Yet since private schooling also promotes access to scarce good jobs, and since value-sharing is thought to contribute to that advantage (Ashley et al., 2015), the social and spatial proximity of like-for-like school types can continue after the end of full-time education.

Our hypothesis, therefore, is that school-type homogamy arises both indirectly as the by-product of educational homogamy and private school educational quality, and directly since private schooling augments the extent to which values and social networks are shared. Formally, we conceive the high educational quality of private schooling for either females or males in the form of a latent quality index, $\tau_{i}^{*}$ which positively affects the quality of schooling of either wife or husband 
( $\mathrm{i}=\mathrm{w}, \mathrm{h})$ and hence the achieved education level $\left(S_{i}\right)$, according to a standard educational production function $S_{i}=f\left(\tau_{i}^{*}, x_{i}\right)$, with

$$
\partial S_{i} / \partial \tau_{i}^{*}=f_{\tau_{i}^{*}}>0, i=w, h \text { with } \mathrm{x} \text { a vector of }
$$

all other factors affecting educational achievement. Here, for ease of exposition, we treat $S_{i}$ as a continuous indicator, though this is operationalised conventionally below as discrete education levels, and we later operationalise $\tau_{i}^{*}$ with a dummy indicator for private schooling. Then, the hypothesis can be expressed in terms of the relationship between the husband's and wife's school qualities resulting from the marriage match, with both an indirect term linked to education-level homogamy $\left(\partial S_{h} / \partial S_{w}>0\right)$ and a direct term:

$$
\partial \tau_{h}^{*} / \partial \tau_{w}^{*}=\alpha \partial S_{h} / \partial S_{w}+\beta(S)>0
$$

Here, $\alpha$ is capturing the extent to which educational homogamy is reflected earlier in the school-type (because of private school quality), while $\beta(S)>0$ is a parameter capturing the extent to which a rise in school quality of the wife is directly associated, as a consequence of shared values and networks, with an increased school quality of the husband. As suggested above, social networks will be broadened for those who attend university, despite some degree of private school concentration within universities; hence we expect that $\beta^{\prime}<0$.

In the light of this hypothesis of school-type homogamy, there are two arguments as to why there could be a premium for women in Britain from private schooling, manifested in the earnings of their husbands. First, their private schooling delivers higher educational achievement, which as a result of educational homogamy implies that their husbands have higher educational achievement than those of state-educated women, which yield them higher wages. Second, with school-type homogamy their husbands are more likely to be privately educated, and this yields an additional boost to their earnings. Studies variously reveal a large pay premium for private schooling in Britain, or a substantially greater chance of being in the top earnings decile, or of attending a high-status occupation, or of avoiding downward social mobility
(Dolton \& Vignoles, 2000; Naylor, Smith \& McKnight, 2002; Dearden et al., 2002; Crawford \& Vignoles, 2014; Macmillan, Tyler \& Vignoles, 2015; Crawford \& van der Erve, 2015; Green et al., 2012; Green et al., 2017a; Green et al., 2018). For women, much or all of this return is accounted for by their educational attainment, but for men there remains a direct pay premium, over and above that which can be explained by their educational credentials.

Formally we assume, as is conventional, that men will participate in the labour force and will receive an income $\left(Y_{h}\right)$ according to a human capital earnings function, commensurate with their education achievement and private schooling:

$$
Y_{h}=g\left(S_{h}, \tau_{h}^{*}\right)>0 \text { with } g_{S h}>0, g_{\tau_{h}^{*}}>0
$$

Combining this human capital earnings function with the hypothesised school-type homogamy (1), along with education level homogamy and the quality of private education, it is thus hypothesised that a woman's private education will be associated with having a more-educated, more likely privatelyeducated, and higher-earning husband:

$$
\partial Y_{h} / \partial \tau_{w}^{*}=g_{S_{h}} f_{\tau_{w}^{*}} \partial S_{h} / \partial S_{w}+g_{\tau_{h}^{*}}\left[\alpha \partial S_{h} / \partial S_{w}+\beta(S)\right]>0
$$

This expression shows that a positive return to marriage for women's private education decision, in the form of the husband's income, stems from two elements. One element derives from a combination of the woman's educational benefits from the private schooling $\left(f_{\tau_{w}^{*}}\right)$, the positive homogamy by education level ( $\partial S_{h} / \partial S_{w}$ ) and the earnings benefits of that extra education $\left(g_{S_{h}}\right)$. The second element stems from the "direct pay premium" $\left(g_{\tau_{h}^{*}}\right)$ in combination with school-type homogamy, both direct $(\beta)$ and indirect via education-level homogamy $\left(\partial S_{h} / \partial S_{w}\right)$. Without any direct pay premium for men's private schooling, the benefit would be purely a by-product of the education level homogamy.

Consistent with the hypothesis of school-type positive homogamy, Evans and Tilley (2011) report, using the British Social Attitudes Survey, that privately educated people are more likely to marry other privately educated people. Similarly, Power, Sims and Whitty (2013) mention that among those who had gone through the Assisted Places Scheme 
- a government-funded programme (1981-1997) for low-income pupils to attend private secondary schools - one in four of those cohabiting had privately-educated partners. Yet beyond these simple descriptive findings, there have been no studies, to our knowledge, of school-type homogamy as a sub-category of education homogamy, either in Britain or in any other country that resembles Britain through having relatively exclusive private schooling alongside a state system. In the context of the especially elite private school system in Britain, this represents an important gap in our understanding of the value of a private school investment and of the origins of low social mobility.

Nor have any studies, to our knowledge, examined the association between school-type and returns through marriage. However, two tangential studies focusing on university type are relevant to note at this point, each from countries that have an elite private education sector, namely Chile and the US. Kaufmann, Messner and Solis (2015) report that going to a higher-ranking university in Chile in the early 2000s meant that women were likely to marry someone who had scored more highly on the university admissions test. Meanwhile, Arum, Roksa and Budig (2008) report that, for a cohort of older graduates in the United States, going to a more elite university had raised the probability of marrying socially privileged spouses. For women, the pay-off was to marry husbands with higher income.

Our main aim is thus to investigate two hypotheses:

H1: There is predicted to be homogamy by school-type in Britain. We expect to find this, both with the raw data on school type and after conditioning on women's education and social background. If confirmed, does the homogamy diminish in magnitude, as predicted, among those with a university-level education?

$\mathrm{H} 2$ : For married women, there is predicted to be an association between whether they have attended private schooling and their husbands' earnings.

\section{Data}

To address these questions, we required British data on households, covering both marriage partners' earnings and school-types, educational achievement data, and adequate controls for social background. Accordingly we combined data from the British Household Panel Survey (BHPS) and
Understanding Society (the UK Household Longitudinal Study: UKHLS). BHPS was an annual panel study of each adult member of a representative sample of households in the UK between 1991 and 2008. UKHLS, from its second wave on, incorporated the BHPS sample, thus enabling us to track the original BHPS sample members and their current circumstances up until the latest UKHLS wave. ${ }^{4}$

In line with the majority of papers examining homogamy, our primary focus is on married, rather than cohabiting couples. This decision is motivated by indications that cohabiting but unmarried matches are much less durable (though some are a prelude to marriage) (Ermisch \& Francesconi, 2000) and do not always involve full income-sharing between partners (Winkler, 1997; Hiekel, Liefbroer, \& Poortman, 2014). Nevertheless, we test whether our findings are sensitive to this choice.

By selecting observations from women who were between 24 and 59 years old and their husbands, our sample is restricted to women below normal retirement age, almost all of whom had finished their initial cycle of full-time education. This leaves us with an unbalanced panel of approximately 72,000 person-year observations of 8,167 women, of which close to 43,000 observations were within marriages spanning the whole of Britain from 1991 to 2013. Respondents were asked once, when they joined the survey (or, in the case of the children in the households of panel members, when they were rising 16), to 'look at this card and tell me what type of school (you are attending/you attended last)'. We coded a binary $0 / 1$ indicator variable to distinguish state-educated and privately-educated respondents according to whether they had last attended a private (that is, fee-paying) school; $6 \%$ stated that they had attended private school. This indicator is less than perfect, in that it does not capture the number of years that the panel members may have spent at private school; nevertheless, the last school attended should still be relevant for capturing school-type associations with values, networks, post-school activities and partner-selection.

For the analyses of husband's earnings, we also show findings derived from the age 42 wave of the British Cohort Study (BCS), a survey of people born in Britain in a single week in 1970 (Elliott \& Shepherd, 2006). On one hand these additional findings provide a robustness check on the broad 
conclusions from the BHPS-UKHLS analyses, albeit using weekly, rather than hourly, pay. On the other hand the BCS contains high-quality, rich social background data derived from the childhood waves (at birth and at ages 5, 10 and 16), which enable us to control for an especially rich set of potentially confounding variables. We include, first, indicators of socio-economic background during childhood: parent's social class at cohort member's birth (highest of father or mother), parents' highest education level when the child was age 5 , housing tenure type (at age 5), persons per room ratio (at age 5), number of days read to in a reference week at age 5 (a measure of cultural capital), mother's age at birth, receipt of free school meals at school at age 10 (a commonly used indicator of social deprivation) and banded family income at age 10 . Second, we control for cohort members' early cognitive developments using indicators collected at ages 5 and 10 (Parsons, 2014). Third, we control for three personal characteristics typically associated with later development: birth order, weight at birth, and whether ever breast-fed. Finally, we include two standard demographic controls: ethnicity, and current region of residence. ${ }^{5}$ The BCS school-type indicator we use is private school attendance at age 16. For this we used information from the 1986 Head Teacher's Questionnaire, but where this variable was missing we used the 1986 Schools Census; where information from 1986 was unavailable, we deployed an indicator derived from a retrospective question in the age 42 survey. ${ }^{6}$ We excluded those from Special Needs schools (whether private or state). In BHPS-UKLHS the participation indicator is, for most respondents, a retrospective measure.

There are, however, issues of attrition and item non-response that needed addressing. ${ }^{7}$ The age 16 survey wave remains broadly representative for important demographic characteristics (gender, parents' ages of leaving full-time education, biological parenthood, ethnicity and country) (Mostafa \& Wiggins, 2015). Nevertheless, to avoid a substantive loss of information and representativeness that would arise by looking only at cases with full information on all waves, following (Schafer, 1997; Little \& Rubin, 2002; Carpenter \& Kenward, 2013) we applied multiple imputation to handle any item missingness for those cases with complete observations on husband's earnings and school type.

Further variable details and descriptive statistics from both data sets are given in the appendix.

\section{School-type homogamy}

We first investigate school type homogamy, beginning with a simple description of marriage frequencies and partners' school-type, using BHPSUKHLS - see table 1. Among those that were married, there is strong indicative evidence for school type homogamy: while $13 \%$ of privately educated women were married to privately educated husbands, this was the case for only $3 \%$ of state school educated women.

One way to summarise the presence of homogamy is the local log odds ratio that compares the frequency of people in homogamous couples to that of people in non-homogamous couples (for each pair of school types) (Siow, 2015). Let $\mu_{\tau_{w}, \tau_{h}}$ be the absolute frequency of marriage between women of school type $\tau_{w} \in[0,1]$ with men of school type $\tau_{h}$. If there is positive homogamy, the index $\mathrm{m}=\ln \left(\left[\mu_{1,1} \cdot \mu_{0,0}\right]\left[\mu_{0,1} \cdot \mu_{1,0}\right]^{-1}\right)$ will be positive. This metric has been interpreted as the 'force of attraction' (Bičáková \& Jurajda, 2016) and is related to the 'surplus' from marriage in

Table 1: Marital status and partner's school type by women's school type.

Pooled BHPS-UKHLS 1991-2013; row percentages. N=72,037.

\begin{tabular}{|l|c|cc|}
\hline $\begin{array}{l}\text { Women's } \\
\text { School } \\
\text { Type }\end{array}$ & Not married & \multicolumn{2}{|c|}{$\begin{array}{c}\text { Married } \\
\text { Partner's School Type } \\
\text { Private }\end{array}$} \\
\hline Private & 33.9 & 13.3 & State \\
State & 37.9 & 3.1 & 52.9 \\
\hline Total & 37.7 & 3.7 & 59.0 \\
\hline
\end{tabular}


economics studies of partner choice (Choo \& Siow, 2006; Menzel, 2015). With our data we find that $m$ $=1.58$ for school-type homogamy, and significantly above zero $(p=0.000)$. This index compares with a value of $m=2.32$ for homogamy by education-level (graduate/non-graduate).

Since private schooling is socially exclusive, given its high price for most pupils, school-type homogamy is likely to reflect, in part, the social closure brought about by social background. To what extent, then, is the school-type of the husband associated with a woman's private school attendance per se, after controlling for her social class background, as implied by the hypothesis of equation (2)? To examine this question, we restrict our attention to married women and estimate four probit models, the results of which are summarised in table $2 .^{8}$ In each the private school dummy is interacted with age groups, to allow for different effects at varying life course stages, and the table presents the average marginal effects of private school attendance on the probability of being married to a privately educated husband.

In the first column, only age group and ethnicity are controlled for, and the estimated coefficient approximately restates what was revealed in the descriptive table above, showing a large tendency for school-type homogamy. There is a 14 percentage point higher chance of being married to a private-school-educated husband for a woman who is privately educated than for a woman who is state educated.

In column 2, we also include as controls the women's social background. Compared with column (1) the estimated degree of school-type homogamy is substantially reduced by about a half. As expected, part of the preference for private school educated spouses can be attributed to the social background that usually determines private school participation. Yet even after accounting for social background, attending private school still raises the probability of being married to a privately educated husband by 7 percentage points. This is our best estimate describing school-type positive homogamy among observably similar women. However, we caution that, if interpreted as a causal effect, it could be biased if there are elements in the individuals' background not captured by parental social class and parental education, which affect both choice of school type and the likelihood of partnering with a privately-educated husband.

The hypothesis of equation (1) is that schooltype homogamy potentially derives from two elements, one being a by-product of educationlevel homogamy, the other being an additional direct element. The education-level element here is binary: whether or not the women obtained higher education. To what extent, then, is the homogamy just a reflection of achieving higher education? Column (3) adds to the model a dummy for women's attainment of higher education. As can be seen, while higher education in itself increases the chances of being married to a privately educated husband, private-school-educated women were still 6 percentage points more likely to be married to a man of the same school type. Thus the school-type homogamy cannot be explained by the woman's educational level and social background. We take this as indicative of a positive average value for $\beta$, reflecting the direct element of the tendency for school-type homogamy.

But is this direct element less strong, as expected, among those who do go on to higher education, than among those who leave education at the secondary stage? Column (4) introduces an interaction term between higher education and private schooling. Among those who do not proceed to higher education, the chances of being married to a privately educated husband are 11 percentage points higher for privately educated women, as compared with state-educated women. Among those who do proceed to higher education, however, the chances are not significantly associated with private school status. Thus, while educational homogamy is a route through which school-type homogamy takes place (private schools raise entry to higher education, which itself raises the probability of school-type homogamy), nevertheless within that higher level of education school-type homogamy is attenuated, as expected, reflecting the wider social and cultural environment of university life and beyond. In this sense, the experience of higher education involves a reduction of social boundaries.

\section{Females' private schooling and their husband's earnings}

Given that there is education-level homogamy, that private schools in Britain are of high quality as 
measured by their pupils' educational achievements, and that in addition there is schooltype homogamy in Britain, do privately-educated married women benefit from a premium on their husbands' earnings over those of state-educated women, as hypothesised in equation (4)?

From this point on, we are able to address our key questions using both sets of data. Using BHPSUKHLS, table 3a shows the descriptive pattern of husbands' real gross monthly earnings, according to the school-types of each partner. As shown in the final column, women's private school attendance is associated with higher-earning husbands. The spouse of the average state-educated married women earned around $£ 2,794$ per month compared to $£ 3,686$ among women who attended private school - a raw premium of $32 \%$. It is also of note that, among married women who attended private school, those in homogamous unions had on average husbands with the greatest gross monthly labour income $(£ 3,834)$. Using BCS, table $3 b$ shows that, at age 42 , the raw weekly husband's earnings gap by school type was substantially higher at $62 \%$.

Table 2: School-Type Homogamy: Probably of marriage to a privately educated spouse

Pooled BHPS-UKHLS 1991-2015. Average marginal effects

(1)

(2)

(3)

(4)

Private School

$0.140^{* * *}$

(0.031)

$0.0737^{* *}$

$0.0618^{* *}$

Higher Education

$0.0502^{* *}$

$0.0579^{* *}$

(0.017)

$-0.00613$

Private School (within

graduates)

$0.107^{* *}$

Private School (within non-

(0.036)

graduates)

\begin{tabular}{lcccc}
\hline Demographics (R) & $X$ & $X$ & $X$ & $X$ \\
Social Background (R) & & $X$ & $X$ & $X$ \\
\hline$N$ & 42,957 & 42,957 & 42,957 & 42,957 \\
\hline
\end{tabular}

Notes: Pooled probit estimator using the cross-sectional survey weights with robust standard errors in the unbalanced panel of married women aged 24-59 years. Dependent variable is 1 if partner has attended a private secondary school and zero otherwise. All models include a set of period dummies and a London dummy to account for differences across time and regions. Demographics comprise age-groups and ethnicity; social background is captured by highest parental socio-economic group and level of educational attainment. Women's highest level of educational achievement is captured by an indicator for higher tertiary educational attainment. Private school effect averaged over age-groups. Standard errors in parentheses. ${ }^{*} p<0.1,{ }^{* *} p<0.05,{ }^{* * *} p<0.001$

Table 3a: Husbands' real gross monthly earnings among married women in GBP (CPI 2015=100)

Pooled BHPS-UKHLS 1991-2015, N=29,103

\begin{tabular}{|c|c|c|c|}
\hline \multirow{2}{*}{$\begin{array}{l}\text { Women's school } \\
\text { type }\end{array}$} & \multicolumn{3}{|c|}{$\begin{array}{c}\text { Married } \\
\text { Partner's school type }\end{array}$} \\
\hline & Private & State & Mean \\
\hline Private & $3,833.85$ & $3,621.02$ & $3,685.52$ \\
\hline State & $3,314.53$ & $2,763.44$ & $2,794.19$ \\
\hline Mean & $3,408.26$ & $2,806.07$ & $2,844.68$ \\
\hline
\end{tabular}




\section{Table 3b: Husbands' weekly earnings among married women in GBP}

BCS-70, 2012, N=2,036

\begin{tabular}{|l|c|}
\hline $\begin{array}{l}\text { Women's school } \\
\text { type }\end{array}$ & $\begin{array}{c}\text { Mean } \\
\text { spousal } \\
\text { earnings }\end{array}$ \\
\hline Private & 930.16 \\
State & 575.75 \\
\hline Mean & 635.22 \\
\hline
\end{tabular}

We address the questions formally in tables 4 a and $4 \mathrm{~b}$. Our basic estimating model operationalises equation (3) by treating private school status as a $0 / 1$ dummy categorical variable $\left(\tau_{w}\right)$ :

$Y_{h}=a_{0}+a_{1} \tau_{w}+a_{2} \sum_{l} \phi^{l} Z_{w}^{l}+\varepsilon_{h}$, with $E\left(\varepsilon_{h}\right)=0$

The $Z_{w}^{l}$ are observables capturing demographic characteristics (age, ethnicity, region), social class background, prior cognitive skills (BCS only), and birth characteristics (BCS only), which could be correlated with husbands' labour market outcomes as well as with women's own school-type, as described above. The first model (in both 4a and 4b) gives the estimates for $a_{1}$ with just the demographic characteristics included. Then the second model shows our core estimates of equation (4), including the whole range of other controls, giving the associations of husbands' earnings with women's school-type for observably similar women. We also include a third model that adds in indicators of the husband's social class, school type and education achievement, in order to see whether the private school premium we are investigating can be crudely accounted for by those characteristics.

To investigate outcomes other than just the mean linear effect on hourly earnings, we also investigate whether there are associations with husbands' earnings being in the top decile of the distribution, as well as the opposite association with husbands' earnings being in the bottom half of the distribution (thereby helping to protect against downward social mobility). We also examine the association of women's private education with their husband's attainment of a high occupation status (a professional or managerial job).

Estimator choice depends on the scale of the dependent variable and follows standard practices. For binary outcomes we employ a probit estimator. In all models shown, the tables report average marginal effects (AME). Since private school attendance is a time-constant individual characteristic in BHPS-UKHLS, we rely on crosssectional estimators. To account for the repeated observations within individuals over time in the panel, potential heteroscedasticity, and changes in composition due to sample attrition, we use the supplied cross-section survey weights and a robust variance-covariance matrix in the estimations. With the BCS data, given that multiple imputation has been used for some variables, as recommended by Carpenter and Kenward (2013) we present estimates derived from 20 alternative imputation outcomes, using the Stata multiple estimation routines, with robust standard errors.

In this set-up there are inevitable limitations and caveats that would have to be borne in mind if the estimates were to be interpreted as implying causal effects of private schooling and if they were to be used to compute women's choice-relevant investment returns from private schooling via marriage. The main complication arises from the two-sided nature of the matching processes. In our data, we are able to observe neither all the feasible matching alternatives nor all the relevant factors that might inform the marriage decision. Thus unobservables on both sides may confound the estimates if they are related to the participation in 
private secondary education. We return to these caveats in the concluding discussion below.

Column (1) shows a substantial association with husbands' outcomes after controlling just for demographic characteristics. Married women who had attended private schools were matched with men who were considerably more successful in the labour market than the husbands of state-school educated women. In the case of the BHPS-UKHLS data, the husbands of these women received on average $26.0 \% \quad(=\exp (0.231)-1)$ higher hourly earnings. In the case of the BCS, the privately educated age-42 cohort members' husbands received $37.9 \% \quad(=\exp (0.327)-1)$ higher weekly earnings. With both data sets, the husbands of the privately educated women were significantly more likely to be in the top (>=90\%) earnings decile, more likely to work in high status, managerial or professional occupations, and less likely to earn incomes below the median.

Some of these effects may be attributable in part to respondents' social background. Privateschool-educated women are more likely to come from well-off families (Dearden et al., 2011), increasing the opportunity to access marriage networks of potential high earners. Hence we condition on respondents' social background, to give the estimates from equation (5). While the controls reduce the estimates substantially - see the average marginal effects in column (2) compared with those in column (1) - the remaining effects are still quantitatively significant. The conditional husbands' pay premium is $15 \%$ for hourly earnings in the BHPS-UKHLS, and $20 \%$ in BCS.

Similarly, the husbands of privately educated women remained more likely to be situated in the top earnings decile and to work in high-status occupations. Spouses of privately educated women were 10 percentage points more likely to be in the top pay decile as the husbands of state-educated women (8 points for BCS at age 42), and again 10 percentage points more likely to work in a highstatus occupation (BHPS-UKHLS) though this effect is insignificant in the BCS data. In the BCS data (but not with the BHPS-UKHLS) there is also a weakly statistically significant protective effect of private school attendance against below-median earnings husbands, lowering that probability by 8 percentage points.
Column (3) in each table adds controls for husband's characteristics and respondent's postsecondary educational attainment (graduate/nongraduate). These reduce the average marginal effects considerably and in some cases the effect is not statistically significant, indicating that these characteristics mediate much of the association with husbands' outcomes. However, in two cases (top earnings for the BHPS data, log earnings for the BCS) the association remains weakly statistically significant. In these cases the estimates imply that private-educated women are matched with partners that earn more than their observed characteristics suggest on average. We conclude there are some unobserved husband characteristics associated both with their pay and with their wives' school type; in the case of the BCS this could include the husband's school-type which is unobserved.

So far our sample has excluded cohabiting but unmarried couples from the analyses. We do not have information about intra-household resource sharing in our data sets, but it could be expected that resources are shared at least partially among a substantial proportion of cohabiting, unmarried couples. For these, similar arguments about schooltype homogamy and education-level homogamy apply. We therefore re-ran our analyses including all cohabiting couples, whether married or not. We found the same pattern of results with only small changes in the estimated coefficients. As a further test of robustness, we took account of differences within the state sector of education, distinguishing between grammar schools, which are academically selective schools available in a minority of regions of Britain, and all other state schools that are not permitted to select on academic merit. Including a separate dummy variable for grammar school attendance made only small differences to the estimated associations of private school attendance with subsequent marriage to a privately educated man, and with the husbands' labour market outcomes. Since a few women at the age of 24 may still have been in full-time education such as in postgraduate research programmes, we also run a robustness check with a BHPS/UKHLS sample limited to the age bracket $30-59$ years. This has no effect on the estimated patterns. ${ }^{9}$ 
Table 4a: Husbands' labour market outcomes, pooled BHPS/UKHLS 1991-2015

\section{(1)}

Private School

$\mathrm{N}$

Private School

N

Private School

$\mathrm{N}$

Private School
$0.228^{* * *}$
(0.045)

28,660
(2)

(3)

(I) Log real hourly pay (log points)

$\begin{array}{ll}0.142^{* *} & 0.0667 \\ (0.045) & (0.042) \\ 28,660 & 28,660\end{array}$

(II) Real hourly earnings in $90 \%$ decile of distribution (AME)
$0.161^{* * *}$
$0.0999^{* *}$
$0.0548^{* *}$
(0.034)
(0.031)
(0.024)
28,961
28,961
28,961

(III) Real hourly earnings in the bottom half of distribution (AME)

$\begin{array}{ccc}-0.0771^{* *} & -0.0168 & 0.0358 \\ (0.029) & (0.033) & (0.033) \\ 28,961 & 28,961 & 28,961\end{array}$

$\mathrm{N}$

$0.184^{* * *}$

(IV) High Status Occupation (AME)

(0.032)

$0.0930^{* *}$

0.0287

35,209

(0.034)

(0.030)

Demographics (R)

35,209

35,209

Social Background (R)

$\mathrm{X}$

$\mathrm{X}$

$x$

$\mathrm{X}$
$\mathrm{X}$
$\mathrm{X}$

Hemer Education (R)

Background, Higher

$x$

Education (H)

Notes: Pooled estimations using cross-sectional survey weights and a heteroscedasticity and autocorrelation robust variancecovariance matrix. Unbalanced panel of married women aged 24-59 years. Dependent variables: (I) husbands' usual log real gross hourly earnings; (II) dummy if husbands' real gross hourly earnings were in $90 \%$ decile; (III) dummy if husbands' real hourly earnings were below the grand median of the hourly earnings distribution; (IV) dummy if husband holds a high status occupation (SOC1990 or SOC2000, major groups 1\&2). Including a set of period dummies for survey period and region of residence. For social background and education, see notes to table 2 . Model 3 adds a range of husbands' observed characteristics (5-year age dummies, ethnicity, parental socio-economic group, parental level of education, private school attendance, and tertiary attainment). Standard errors in parentheses. Private school effect averaged over age-groups. ${ }^{*} p<0.1,{ }^{* *} p<0.05,{ }^{* * *} p<0.001$ 
Table 4b: Husbands' labour market outcomes, BCS-70, age 42

\section{(1)}

Private School

$0.327^{* * *}$

(0.068)

2,028

$\mathrm{N}$

Private School

$0.172^{* * *}$

(0.039)

2,028

$\mathrm{N}$

Private School

$\mathrm{N}$

Private School

$0.102^{* *}$

(0.032)

2,509

$\mathrm{N}$

Demographics

Childhood cognitive

$\mathrm{X}$

attainment, social

background ( $R$ )

Higher education $(R)$

Partner's age, level of

education $(\mathrm{H})$

(2)

(3)

(I) Log weekly earnings

$\begin{array}{cc}0.184^{* *} & 0.125^{*} \\ (0.073) & (0.069) \\ 2,028 & 2,028\end{array}$

(II) Weekly earnings in 90\% Decile. AME

$\begin{array}{cc}0.0728^{* *} & 0.0423 \\ (0.036) & (0.033) \\ 2,028 & 2,028\end{array}$

(III) Weekly earnings below the median. AME
$-0.137^{* *}$
$-0.0790^{*}$
(0.043)
$-0.0523$
$(0.045)$
2,028
2,028
2,028

(IV) High Status Occupation. AME

$\begin{array}{cc}0.0200 & -0.0206 \\ (0.027) & (0.022) \\ 2,509 & 2,509 \\ X & X \\ X & X\end{array}$

Notes: Mean differences in spousal labour market outcomes by female private school attendance. (I) Effect on log weekly earnings. (II)/ (III) differences in the likelihood of spousal income in the $90^{\text {th }}$ percentile/ below the median. Cut-points derived from BCS. (IV) female private school effects on likelihood to match with spouse in higher managerial and professional occupations (based on NSSEC groupings). Column (1) reports differences adjusted by demographic characteristics (ethnicity, region of residence). Column (2) adds controls for socio-economic background during childhood (social class at birth, parental educational attainment, housing tenure, persons per room ratio, number of days read to in reference week, free school meal receipt, family income band), information on early cognitive developments at age 5 and 10, and controls for mother's age at birth, birth order, weight at birth and whether ever breast-fed). To address missingness, estimations based on multiple imputations. Standard errors in parentheses ${ }^{*} p<$ $0.1,{ }^{* *} p<0.05,{ }^{* * *} p<0.001$ 


\section{Conclusion}

In this paper we have presented evidence that there is a substantive degree of school-type homogamy in Britain, whereby a privately educated woman, compared with a state-educated woman with otherwise similar social background, is 7 percentage points more likely to marry a privately educated man. Our explanation is that homogamy by school-type partly reflects education-level homogamy, owing to the high quality of private schooling in Britain, but that it also follows directly from shared values and networks inculcated in private schools. We found that homogamy by school-type is especially strong among nongraduates, and absent among graduates, testimony to the widening social environment associated with university life and beyond.

We have also found that the husbands of privately educated women have an estimated $15 \%$ greater hourly pay using BHPS-UKHLS, and 20\% greater weekly pay using age $42 \mathrm{BCS}$ data, than the husbands of state-educated women. The husbands of the privately-educated were much more likely to work in high status occupations, more likely to be earning in the 90th percentile, and less likely to be earning below the median, than the husbands of the state educated.

A number of limitations to the analysis should be noted. We have reasonable controls for social background and educational credentials, including especially good ones in the BCS data. However, some other factors that are unobserved, such as parental attitudes, could be positively related both to private school choice and the matching outcomes investigated. If so, any causal effect of private school attendance would be lower than our estimates of the conditional association suggest. Measurement error of school-type, on the other hand, might suggest an underestimate of its effects. Even though school-type when leaving school is accurately recorded in retrospect by the vast majority of cases, we do not have information on the length of time in private school, or on differences in private school quality. Finally, another issue is that surveys such as BHPS/UKHLS and BCS do not adequately track those going abroad. There are relatively few of these, but especially in recent years, when some elite schools have become the training ground for some high earners in a globally integrated world, trimming from the sample those who leave the country might alter the estimated association with private school attendance. $^{10}$

Nevertheless, the finding of strong relationships between females' private schooling and their husbands' earnings raises anew the issue of the negative association between private schooling and social mobility. This link is already implied by the labour market returns enjoyed by both men and women, and the exclusivity in access implied by the relatively high fees charged in most schools. The findings in this paper reinforce this link: school-type homogamy, and associated educational homogamy, combine to help retain economic and social advantages within the family. In asking whether private school girls marry rich, a natural extension of this line of research would be to examine the accumulated wealth of partners, and the consequent links with household income. Future research can also be extended to the marriage returns for males. One would expect to find similar effects in other countries or regions where private education is both sharply separated from the state in governance and funding, and associated with high earnings. Other sharp institutional dividing lines in education with potential implications for adult social and economic outcomes, such as between religious and secular schools, may also provide fruitful areas for research on homogamy linked to school type, though in such cases the school typology might reflect a different institutional dichotomy, more salient for different countries or contexts.

Our findings also may have implications for school choice by parents, seemingly raising the returns to private education. One potential further extension to the analysis of school-type homogamy would be to allow for the prospective marriage market return to affect the choice of private education and, further, the level of investment. Chiappori, lyiguin and Weiss (2009) developed a model of equilibrium education and marriage choice in the presence of educational homogamy underpinned by complementary preferences. In empirical work Ge (2011) and Lafortune (2013) each report effects of changing marriage prospects on college educational investments in the US. Yet the possibility that choice of school-type in Britain is also affected by marriage prospects is a further reason for caution in interpreting our findings as unbiased estimates of causal effects. 


\section{Acknowledgements}

This work was funded by the ESRC-funded LLAKES Centre for Research on Learning and Life Chances with an additional contribution to LLAKES from the ESRC/UKCES Strategic Partnership (ES/J019135/1). The research was also supported through a separate ESRC grant "Schooling and Unequal Outcomes in Youth and Adulthood" (ES/K007238/1).

\section{References}

Antonovics, K. \& Town, R. (2004). "Are All the Good Men Married? Uncovering the Sources of the Marital Wage Premium." The American Economic Review, 94(2), Papers and Proceedings: 317-321.

Arum, R., Roksa, J. \& Budig, M. J. (2008). "The romance of college attendance: Higher education stratification and mate selection." Research in Social Stratification and Mobility, 26, 107-121. https://doi.org/10.1016/i.rssm.2008.02.003

Ashley, L., Duberley, J., Sommerlad, H., \& Scholarios, D. (2015). A qualitative evaluation of non-educational barriers to the elite professions. London: Social Mobility and Child Poverty Commission.

Bičáková, A., \& Jurajda, Š. (2016). "Field-of-Study Homogamy." IZA Discussion Paper Series, (9844), 1-34.

Blackwell, D. L. (1998). "Marital homogamy in the United States: The influence of individual and paternal education." Social Science Research, 27(2): 159-188. https://doi.org/10.1006/ssre.1998.0618

Blandford, L. (1977). "The making of a lady." In G. Macdonald-Fraser (ed.), The World of the Public School. London: Weidenfeld \& Nicolson.

Blossfeld, H.-P. (2009). "Educational Assortative Marriage in Comparative Perspective." Annual Review of Sociology, 35(5), 513-530. https://doi.org/10.1146/annurev-soc-070308-115913

Blossfeld, H.-P. \& Buchholz, S. (2009). "Increasing resource inequality among families in modern societies: The mechanisms of growing educational homogamy, changes in the division of work in the family and the decline of the male breadwinner model." Journal of Comparative Family Studies, 40(4), 603616.

Blossfeld, H.-P. \& Timm, A. (2003). Who marries whom?: educational systems as marriage markets in modern societies. Springer Science \& Business Media. https://doi.org/10.1007/978-94-007-1065-8

Boliver, V. (2013). "How fair is access to more prestigious UK universities?" The British Journal of Sociology, 64 (2), 344 - 364. https://doi.org/10.1111/1468-4446.12021

Breen, R. \& Andersen, S. H. (2012). "Educational Assortative Mating and Income Inequality in Denmark." Demography, 49(3), 867-887. https://doi.org/10.1007/s13524-012-0111-2

Bukodi, E. \& Goldthorpe, J. H. (2011). "Class Origins, Education and Occupational Attainment in Britain: Secular Trends or Cohort-Specific Effects?" European Societies, 13(3), 347-75. https://doi.org/10.1080/14616696.2011.568259

Carpenter, J. \& Kenward, M. G. (2013). Chapter 2 in Multiple Imputation and its application. Chichester: Wiley \& Sons Ltd Statistics in Practice. https://doi.org/10.1002/9781119942283

Chiappori, P.-A., Iyiguin, M., \& Weiss, Y. (2009). "Investment in Schooling and the Marriage Market." American Economic Review, 99 (5), 1689-1713. https://doi.org/10.1257/aer.99.5.1689

Choo, E., \& Siow, A. (2006). Who Marries Whom and Why. Journal of Political Economy, 114(1), 175-201. https://doi.org/10.1086/498585

Cookson, Jr., P. W., \& Persell, C. H. (1985). Comparative Education Review, Vol. 29, No. 3 (Aug, 1985), 283298. https://doi.org/10.1086/446523

Crawford, C., \& van der Erve, L. (2015). Does Higher Education Level the Playing Field? Socio-Economic Differences in Graduate Earnings. Education Sciences, 5(4), 380-412. https://doi.org/10.3390/educsci5040380

Crawford, C., \& Vignoles, A. (2014). "Heterogeneity in graduate earnings by socio-economic background." IFS Working Paper (W14/30): 1-20.

Crawford, C., Goodman, A., \& Joyce, R. (2010), Explaining the Socio-Economic Gradient in Child Outcomes: The Intergenerational Transmission of Cognitive Skills, London: Institute for Fiscal Studies. 
Dearden, L., Ferri, J., \& Meghir, C. (2002). "The effect of school quality on educational attainment and wages." Review of Economics and Statistics, 84(1), 1-20. https://doi.org/10.1162/003465302317331883

Dearden, L., Ryan, C., \& Sibieta, L. (2011). "What Determines Private School Choice? A Comparison between the United Kingdom and Australia." Australian Economic Review, 44(3), 308-320. https://doi.org/10.1111/j.1467-8462.2011.00650.x

Dolton, P. \& Vignoles, A. (2000). The incidence and effects of overeducation in the UK graduate labour market. Economics of education review, 19(2), 179-198. https://doi.org/10.1016/S02727757(97)00036-8

Elder Jr, G. H. (1969). "Appearance and education in marriage mobility." American Sociological Review, 34(4), 519-533. https://doi.org/10.2307/2091961

Elliott, J., \& Shepherd, P. (2006). "Cohort profile: 1970 British birth cohort (BCS70)", International Journal of Epidemiology, 35, 836-843. https://doi.org/10.1093/ije/dyl174

Ermisch, J., \& Francesconi, M. (2000). "Cohabitation in Great Britain: not for long, but here to stay." Journal of the Royal Statistical Society: Series A (Statistics in Society), 163(2), 153-171. https://doi.org/10.1111/1467-985X.00163

Ermisch, J., Francesconi, M., \& Siedler, T. (2006). "Intergenerational Mobility and Marital Sorting." The Economic Journal, 116(513), 659-679. https://doi.org/10.1111/j.1468-0297.2006.01105.x

Evans, G. \& Tilley, J. (2011). "Private schools and public divisions: the influence of fee-paying education on social attitudes". In A. Park, E. Clery, J. Curtice, M. Philips and D. Utting (eds), British Social Attitudes 28. London: Sage, 37-52.

Gathorne-Hardy, J. (1977). The Public School Phenomenon, 597-1977. London: Hodder and Stoughton.

Ge, S. (2011). Women's College Decisions: How Much Does Marriage Matter? Journal of Labor Economics, 29(4), 773-818. https://doi.org/10.1086/660774

Gihleb, R., \& Lang, K. 2016. Educational Homogamy and Assortative Mating Have Not Increased. NBER, Working Paper No. 22927.

Goldin, C., \& Katz, L. F. (2008)._The Race Between Education and Technology. Cambridge, Mass.: Harvard University Press.

Goodman, A., Gregg, P., \& Washbrook, E. (2011), 'Children's educational attainment and the aspirations, attitudes and behaviours of parents and children through childhood in the UK', Longitudinal and Life Course Studies, 2(1), 1-18.

Green, F., Machin, S., Murphy, R., \& Zhu, Y. (2012). "The Changing Economic Advantage from Private Schools." Economica, 79, 658-679.

Green, F., Henseke, G. \& Vignoles, A. (2017) "Private schooling and labour market outcomes". British Educational Research Journal. 43(1), 7-28. https://doi.org/10.1002/beri.3256

Green, F., Parsons, S., Sullivan, A., \& Wiggins, R. (2018). “Dreaming Big? Self-Evaluations, Aspirations, Valued Social Networks, and the Private School Earnings Premium in the UK". Cambridge Journal of Economics.42 (3), 757-778. https://doi.org/10.1093/cje/bex023

Green, F., Anders, J., Henderson, M., \& Henseke, G. (2017). Who Chooses Private Schooling in Britain and Why? Centre for Research on Learning and Life Chances (LLAKES), Research Paper 62. London.

Greenwood, J., Guner, N., Kocharkov, G. \& Santos, C. (2014). 'Marry Your Like: Assortative Mating and Income Inequality.' American Economic Review, Papers and Proceedings (May), 1-10. https://doi.org/10.3386/w19829

Gregg, P. \& Macmillan, L. (2010), 'Family income, education and cognitive ability in the next generation: exploring income gradients in education and test scores for current cohorts of youth'. Longitudinal and Life Course Studies, 1(3), 259-80.

Halpin, B. \& Chan, T. W. (2003). "Educational homogamy in Ireland and Britain: trends and patterns." The British Journal of Sociology, 54(4), 473-495. https://doi.org/10.1080/0007131032000143546

Hiekel, N., Liefbroer, A. C., \& Poortman, A. R. (2014). Income pooling strategies among cohabiting and married couples: A comparative perspective. Demographic Research, 30, 1527. https://doi.org/10.4054/DemRes.2014.30.55 
Jerrim, J., Parker, P. D., Chmielewski, A. K. \& Anders, J. (2015 online). "Private Schooling, Educational Transitions, and Early Labour Market Outcomes: Evidence from Three Anglophone Countries." European Sociological Review.

Kalmijn, M. (1998). "Intermarriage and homogamy: Causes, patterns, trends." Annual Review of Sociology, 24(1), 395-421. https://doi.org/10.1146/annurev.soc.24.1.395

Kaufmann, K. M., Messner, M., \& Solis, A. (2015). Elite Higher Education, the Marriage Market and the Intergenerational Transmission of Human Capital. Mimeo, European University Institute, Department of Economics Seminar, https://www.eui.eu/Documents/DepartmentsCentres/Economics/Seminarsevents/Kaufmann.pdf.

Kirby, P. (2016). Leading People 2016. London: The Sutton Trust.

Lafortune, J. (2013). "Making Yourself Attractive: Pre-Marital Investments and the Returns to Education in the Marriage Market." American Economic Journal: Applied Economics, 5(2), 151-178. https://doi.org/10.1257/app.5.2.151

Little, R. J. \& Rubin, D. B. (2002). Statistical analysis with missing data. Chichester: John Wiley \& Sons. https://doi.org/10.1002/9781119013563

Macmillan, L., Tyler, C., \& Vignoles, A. (2015). "Who Gets the Top Jobs? The Role of Family Background and Networks in Recent Graduates' Access to High-status Professions." Journal of Social Policy, 44(3), 487-515. https://doi.org/10.1017/S0047279414000634

Maxwell, C. \& Aggleton, P. (2014a). "Agentic practice and privileging orientations among privately educated young women". The Sociological Review, 62(4), 800-820. https://doi.org/10.1111/1467954X.12164

Maxwell, C. \& Aggleton, P. (2014b) "The reproduction of privilege: Young women, the family and private education". International Studies in Sociology of Education, 24(2), 189-209. https://doi.org/10.1080/09620214.2014.919091

McKnight, A. (2015). Downward mobility, opportunity hoarding and the 'glass floor'. London: Social Mobility and Child Poverty Commission.

Menzel, K. (2015). Large Matching Markets as Two-Sided Demand Systems. Econometrica, 83(3), 897-941. https://doi.org/10.3982/ECTA12299

Mostafa, T. \& Wiggins, D. (2015). "The impact of attrition and non-response in birth cohort studies: a need to incorporate missingness strategies." Longitudinal and Life Course Studies, 6(2), 131-146. https://doi.org/10.14301/Ilcs.v6i2.312

Naylor, R., Smith, J., \& McKnight, A. (2002). "Why is there a graduate earnings premium for students from independent schools." Bulletin of Economic Research, 54(4), 315-339. https://doi.org/10.1111/14678586.00155

Parsons, S. (2014). Childhood cognition in the 1970 British Cohort Study (CLS Working Papers).

Peel, M. (2015). The New Meritocracy: A History of UK Independent Schools 1979-2015. London: Elliott and Thompson.

Plewis, I., Calderwood, L., Hawkes, D., \& Nathan, G. (2004). Changes in the NCDS and BCS70 Populations And Samples Over Time. Centre for Longitudinal Studies Technical Report. London: Institute of Education.

Power, S., Whitty, G., \& Wisby, E. (2006). The Education and Career Trajectories of Assisted Place Holders. London: The Sutton Trust.

Power, S., Sims, S., \& Whitty, G. (2013). Lasting Benefits. London: The Sutton Trust.

Reynolds, C. A., Baker, L. A., \& Pedersen, N. L., (2000). "Multivariate models of mixed assortment: phenotypic assortment and social homogamy for education and fluid ability." Behavior Genetics, 30(6), 455-476. https://doi.org/10.1023/A:1010250818089

Schafer, J. L. (1997). Analysis of Incomplete Multivariate Data. London: Chapman and Hall. https://doi.org/10.1201/9781439821862

Schwartz, C. R. (2013). 'Trends and Variation in Assortative Mating: Causes and Consequences.' Annual Review of Sociology, 39, 451-70. https://doi.org/10.1146/annurev-soc-071312-145544

Schwartz, C. R., \& Mare, R. D. (2005). "Trends in educational assortative marriage from 1940 to 2003." Demography, 42(4), 621-646. https://doi.org/10.1353/dem.2005.0036 
Silles, M. A. (2007). "The returns to education for the United Kingdom." Journal of Applied Economics, 10(2), 391-413.

Siow, A. (2015). Testing Becker's theory of positive assortative matching. Journal of Labor Economics, 33(2), 409-441. https://doi.org/10.1086/678496

Sullivan, A., Parsons, S., Wiggins, R., Heath, A., \& Green, F. (2014). "Social origins, school type and higher education destinations." Oxford Review of Education, 40(6), 739-763. https://doi.org/10.1080/03054985.2014.979015

Turner, D. (2015). The Old Boys. The Decline and Rise of the Public School. London: Yale University Press. https://doi.org/10.12987/yale/9780300189926.001.0001

Uunk, W. J., Ganzeboom, H. B., \& Róbert, P. (1996). "Bivariate and multivariate scaled association models. An application to homogamy of social origin and education in Hungary between 1930 and 1979." Quality \& Quantity, 30(3), 323-343.

Walford, G. (1983). "Girls in boys' public schools: A prelude to further research." British Journal of Sociology of Education, 4(1), 39-54. https://doi.org/10.1080/0142569830040103

Winkler, A. E. (1997). Economic decision-making by cohabitors: Findings regarding income pooling. Applied Economics, 29(8), 1079-1090. https://doi.org/10.1080/000368497326471

\section{Endnotes}

1. The following citation from Mail Online, $12 / 2 / 2014$, illustrates this point under the headline: "I spend a fortune to send my girl to private school - so she'll marry rich and never work". The citation proceeds: "my husband ... and I place great importance on her learning. Indeed, we hope she will go on to study at Oxford University, ( ... which is...) the ideal place for her to find a husband with the right background and career prospects to make enough money so Matilda can become a stay at-home mother." See also "Private schools continue to divide 'them and us' Britain", The Week, 2/11/2011; "Kate Middleton's family and the Upper Middleton", Evening Standard, 7/5/2015.

2. A new scheme to enable boarding education for disadvantaged students on the edge of the care system has recently launched on a small scale; see https://www.gov.uk/government/news/more-help-forvulnerable-children-to-attend-top-boarding-schools

3. The source of the superior quality of private schooling in terms of educational outcomes is not fully understood, but is held to lie in some combination of their superior resources, autonomous governance and beneficial peer effects from privileged and supportive social background of the pupils. The resource gap is especially large in Britain, with fees alone being of the order of three times the unit expenditure on state school pupils.

4. https://www.iser.essex.ac.uk/bhps/; https://www.understandingsociety.ac.uk/ Since the specific question on private school attendance is not included in UKHLS, we are unable to incorporate its larger sample.

5. These key indicators could be supplemented by other controls available in the data at various waves, though typically there will be considerable multiple collinearity among the indicators.

6. Inevitably, recall data might be liable to some recall error. Nevertheless where multiple reports of participation were available, the retrospective data proved to be reliable in the large majority of cases: in fewer than $1 \%$ of cases did the age 42 recall data differ from the contemporary information sources (Green et al., 2018).

7. Plewis, Calderwood, Hawkes and Nathan (2004) provide an analysis of all samples up to age 30.

8. Generating a similar pattern of conclusions we also tried an alternative approach, embedding the decision in a multinomial model of marriage and husband's school types, comparing for women the option of remaining unmarried with heterogamous marriage or homogamous marriage. Menzel (2015) shows that for large marriage markets the conditional choice problem can be approximated by a logit model.

9. The findings for both these sensitivity analyses are available on request.

10. Overall, $2 \%$ of the BCS age 16 sample had ever emigrated by age 42 , including $3 \%$ of those at private secondary school. 


\section{Appendix}

This appendix presents details of variable descriptions and tables of descriptive statistics of all variables from both data sets used in our analyses.

\section{$\underline{\text { Table A1 Variable descriptions }}$}

\begin{tabular}{|c|c|}
\hline Variable & Description \\
\hline \multicolumn{2}{|r|}{ Demographics } \\
\hline Age & $\begin{array}{l}\text { Categorical variable. Cutpoints differ between females and males } \\
\text { to account for the persistent age difference in marriages } \\
\text { - Respondents: } 24-29,30-34,35-39,40-44,45-49,50-54 \text {, } \\
\text { 55-59. } \\
\text { - Partner: }<27,27-31,32-36,37-41,42-46,47-51,52-56 \text {, } \\
\text { 57-61, 62+ }\end{array}$ \\
\hline Ethnicity & $\begin{array}{l}\text { Binary indicator to distinguish between whites and non-white } \\
\text { respondents (self-reported) }\end{array}$ \\
\hline \multicolumn{2}{|r|}{ Social Background } \\
\hline Paternal education (at age 14 ) & $\begin{array}{l}\text { Categorical variable that distinguishes between } \\
\text { - Neither parent had formal qualifications } \\
\text { - At least one parent with some qualifications/further } \\
\text { education quals } \\
\text { - At least one parent with a university/higher degree } \\
\text { - No valid data for either parent }\end{array}$ \\
\hline $\begin{array}{l}\text { Paternal socio-economic group class } \\
\text { (at age 14) }\end{array}$ & $\begin{array}{l}\text { Categorical variable that groups parents into } 5 \text { classes based on the } \\
\text { highest reported socio-economic group: } \\
\text { - } \text { High: large managers, large employers, self-employed and } \\
\text { employed professionals } \\
\text { - Intermediate: small managers and intermediate level } \\
\text { supervisors, intermediate level non-manual workers } \\
\text { - Small employers: small employers and own account } \\
\text { workers (non-farm and farm) } \\
\text { - Services: junior non-manual, personal services, armed } \\
\text { forces } \\
\text { - Manual: foreman manual, (semi-)skilled and unskilled } \\
\text { - } \text { manual and agricultural workers } \\
\text { - Othermployed/Inactive: neither parent in paid work }\end{array}$ \\
\hline \multicolumn{2}{|r|}{ Educational Attainment } \\
\hline Educational attainment & $\begin{array}{l}\text { Categorical variable to distinguish between higher tertiary } \\
\text { attainment and below: Higher tertiary }(=1) \text { or lower }(=0)\end{array}$ \\
\hline
\end{tabular}




\section{Table A2: Descriptive statistics, married women, BHPS/UKHLS}

\begin{tabular}{llc} 
Log monthly household income & mean & sd \\
Not in work & 8.223 & 0.603 \\
Private school & 0.269 & 0.444 \\
Tertiary attainment & 0.062 & 0.241 \\
$24-29$ & 0.138 & 0.345 \\
$30-34$ & 0.081 & 0.273 \\
$35-39$ & 0.131 & 0.337 \\
$40-44$ & 0.157 & 0.364 \\
$45-49$ & 0.166 & 0.372 \\
$50-54$ & 0.160 & 0.367 \\
$55-59$ & 0.156 & 0.363 \\
Non-white & 0.148 & 0.355 \\
London & 0.037 & 0.188 \\
\hline 5 & 0.236 & 0.425
\end{tabular}

\section{Parental SEG}

Neither parent had formal qualifications

$0.323 \quad 0.468$

some qualifications/ further education

0.426

0.494

university/ higher degree

0.073

0.259

Missing

0.179

0.383

large managers, large employers, employed professionals

0.165

0.371

small managers and intermediate level supervisors

0.125

0.331

small employers and own account workers

0.131

0.337

junior non-manual, personal services

0.175

0.380

foreman manual, (semi-)skilled and unskilled manual

0.319

0.466

neither parent in paid work

0.043

0.202

no information

0.042

0.201

Highest parental qualification 


$\begin{array}{lcc}\text { no formal qualifications } & 0.323 & 0.468 \\ \text { some qualifications/ further education } & 0.426 & 0.494 \\ \text { university/ higher degree } & 0.073 & 0.259 \\ \text { Missing } & 0.179 & 0.383 \\ N & 44035 & \end{array}$

Table A3: Descriptive statistics, husbands, BHPS/UKHLS

\begin{tabular}{|c|c|c|}
\hline & mean & sd \\
\hline Log hourly wages & 2.641 & 0.608 \\
\hline Earnings in $9^{\text {th }}$ decile & 0.139 & 0.346 \\
\hline Earnings below median & 0.351 & 0.477 \\
\hline SOC MG1/MG2 & 0.351 & 0.477 \\
\hline Private school & 0.060 & 0.238 \\
\hline Higher education & 0.179 & 0.383 \\
\hline 27-31 & 0.015 & 0.122 \\
\hline $32-36$ & 0.084 & 0.277 \\
\hline 37-41 & 0.150 & 0.358 \\
\hline $42-46$ & 0.178 & 0.382 \\
\hline 47-51 & 0.177 & 0.382 \\
\hline $52-56$ & 0.161 & 0.368 \\
\hline 57-61 & 0.132 & 0.338 \\
\hline $62+$ & 0.103 & 0.304 \\
\hline Non-white & 0.035 & 0.183 \\
\hline \multicolumn{3}{|l|}{ Parental SEG } \\
\hline large managers, large employers, employed professionals & 0.162 & 0.368 \\
\hline small managers and intermediate level supervisors & 0.125 & 0.331 \\
\hline small employers and own account workers & 0.124 & 0.330 \\
\hline junior non-manual, personal services & 0.171 & 0.377 \\
\hline
\end{tabular}




$\begin{array}{lll}\text { foreman manual, (semi-)skilled and unskilled manual } & 0.330 & 0.470 \\ \text { neither parent in paid work } & 0.037 & 0.188 \\ \text { no information } & 0.051 & 0.221 \\ \text { Highest parental qualification } & & \\ \text { no formal qualifications } & 0.332 & 0.471 \\ \text { some qualifications/ further education } & 0.428 & 0.495 \\ \text { university/ higher degree } & 0.064 & 0.245 \\ \text { Missing } & 0.175 & 0.380 \\ N & 29347 & \end{array}$

Table A4 Descriptive statistics for the married women in the British Cohort Study at age 42

\begin{tabular}{lcc} 
Annual household income $>f 55.9 k$ & mean & sd \\
Not in work & 0.237 & 0.425 \\
Log Husband's weekly pay & 0.181 & 0.385 \\
Husband's weekly pay in 9 ${ }^{\text {th }}$ decile & 6.167 & 0.676 \\
Husband's weekly pay below median & 0.166 & 0.373 \\
Husband's occupation MG1/ MG2 & 0.313 & 0.464 \\
Private school & 0.138 & 0.345 \\
Higher education & 0.069 & 0.253 \\
At Birth & 0.333 & 0.622 \\
V unskilled & & \\
IV partly-skilled & & 0.203 \\
III manual & 0.043 & 0.353 \\
III non manual & 0.146 & 0.495 \\
II managerial and Technical & 0.431 & 0.359 \\
I professional & 0.152 & 0.368 \\
Other (not in work/ other) & 0.162 & 0.242 \\
\hline
\end{tabular}


Birthweight (in g)

livebaby

Mother's age at birth

Age 5

Breast Feeding

0.407

0.650

0.255

0.050

0.045

1.012

35.600

1.986

4.962

4.709

0.973

0.008

0.018

Other

Age 10

banded family income (1)

0.051

0.264

0.350

0.185

0.080

0.070

0.117

45.978

44.008
0.229

5.248

0.491

0.477

0.436

0.218

0.207

0.250

10.044

4.385

1.900

2.484

0.161

0.091

0.134

0.220

0.441

0.477

0.388

0.272

0.255

0.321

10.925

11.239 
BAS Word Definitions

10.517

4.842

Age 42

Number Of Children in $\mathrm{HH}$

1.840

1.013

North

0.060

0.238

Yorks and Humberside

0.091

0.287

East Midlands

0.072

0.259

East Anglia

0.045

0.208

South East

0.289

0.453

South West

0.105

0.307

West Midlands

0.089

0.284

North West

0.107

0.309

Wales

0.058

0.234

Scotland

0.084

0.278

Partner

Age

44.244

4.558

Age left $\mathrm{ft}$-education $(<18)$

0.612

0.487

Age left ft-education (18/19)

0.152

0.359

Age left ft-education (20/21)

0.087

0.282

Age left ft-education (22/29)

0.135

0.342

Age left ft-education (30+)

0.013

0.115

$N$

2529 